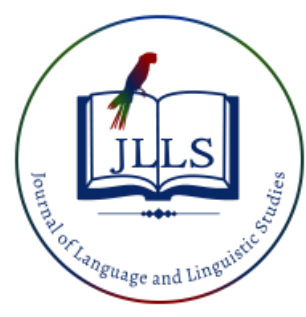

Available online at www.jlls.org

JOURNAL OF LANGUAGE

AND LINGUISTIC STUDIES

ISSN: $1305-578 \mathrm{X}$

Journal of Language and Linguistic Studies, 17(3), 1402-1410; 2021

\title{
Literary myth and journalistic logos: From contrast to integration
}

\author{
Raissa T. Saddykova ${ }^{1 \text { a }}$ iD , Raushan M. Mukhazanova ${ }^{\text {b iD , Assem A. Kassymova }}{ }^{\text {iD , }}$ \\ Gulnur M. Kabdullina ${ }^{\text {d }}$ iD, Assem M. Yelubay e \\ ${ }^{a, b, c}$ Kazakh Humanitarian Law Innovative University, Semey, Republic of Kazakhstan \\ ${ }^{d}$ Shakarim State University of Semey, Semey, Republic of Kazakhstan \\ ${ }^{e}$ Civil Aviation Academy, Almaty, Republic of Kazakhstan
}

\section{APA Citation:}

Saddykova, R. T., Mukhazanova, R. M., Kassymova, A. A., Kabdullina, G. M., Yelubay, A. M. (2021). Literary myth and journalistic logos: From contrast to integration. Journal of Language and Linguistic Studies, 17(3), 1402-1410. Doi: 10.52462/jlls.101

Submission Date20/05/2021

Acceptance Date:21/08/2021

\begin{abstract}
The relevance of the study of productive and creative exchange between literature and journalism is determined by the problematic relation between the two paradigms of the interpretation of reality. The paper covers the opposition and diffusion of literature and journalism. With polarising initiatives, these forms of verbal interpretation of reality have achieved the synergistic effect of their creative integration during their long genesis. The purpose of the study is to identify the conditions for achieving a fruitful synthesis of literary cyclicality and journalistic linearity, which achieves a synergistic effect. Furthermore, the purpose of the study is to clarify the contrast between the cyclicality of the literary image and the linearity of journalistic fact, which underlie the correlation between fiction and non-fiction. The methodological framework of the research includes the principles of historicism, objectivity, consistency, concreteness, methods of source analysis, methods of historical deduction and induction. Based on the results of the study, new scientific data were obtained on the historical specifics of the mutual influence of fine literature on public logos and the reverse interaction of journalistic topicality on the literary canon. The conclusions of the research can be used in the development of new humanitarian solutions in effective dialogue between artistic and literary fiction and actual journalistic factuality.
\end{abstract}

Keywords: genesis of genres; literary cyclicality; journalistic discursiveness; "fiction"; "non-fiction"; "new journalism"

\section{Introduction}

The relevance of the study of productive and creative exchange between literature and journalism is determined by the problematic relation between the two paradigms of the interpretation of reality. In the studies of O. E. Elnikova (2019) and V. A. Slavina (2016), literature is viewed as a phenomenon of rationalising transformation from an archaic myth to the current widest range of genres. The entire variety of sacred initiatory epic and legends from the Book of Changes to Tanakh, from Mahabharata to Theogony laid the foundation for the history of world literature. The general trajectory of genres'

\footnotetext{
${ }^{1}$ Corresponding author.

E-mail address: r.saddykova5723@nuos.pro
} 
genesis was the sequential separation of the vertical of dramatic dialogicity from the horizon of collective epicity, defining the modality of literary cyclicality. Deliberately ignoring the "mythical nature of fictional convention" (Masharipova, 2014), journalism relies on the facts of existing reality, guaranteeing "the adequacy of their connections and opinions with the use of the tools of logical and rhetorical argumentation" (Khasavov, 2019), developing the modality of journalistic linearity.

Also, the relevance of the study is related to the following aspects:

- with the growing role of journalism in society, the activities of the human factor, its influence on all spheres of literary and artistic creativity;

- qualitative changes and approaches of journalism and literature in the process of strengthening personal potential and realism, analytics and stability in literary and journalistic creativity upon assessing complex socio-economic and spiritual processes in the development of society, the expression of modern values, the establishment of a new personality (Smagulov et al., 2014);

- with an understanding of the accumulated experience of fruitful and creative integration of journalism and literature, the necessity of knowing the nature, properties, and directions of the interrelation between journalism and literature, identifying the content, forms of literature and journalistic works, patterns, and trends in the search and development of their expressive means, the specific features of their poetics (Mazhitayeva et al., 2014);

- intensification and generalisation of research on the interrelation between journalism and literature, the rapid implementation of the best practices of literary and journalistic activities of leading masters of speech, which contributes to continuity, the development of personal skills, and an increase in the effectiveness of public opinion (Pavenkov et al., 2018; Issakova et al., 2021).

The term "integration" itself requires clarification. Its root is Latin, integer - whole, integratio - to restore, to replenish. In modern languages, this has long been associated mainly with mathematics and integral calculus. Dal's dictionary does not provide other definitions of this concept (except for mathematics) (Hoque et al., 2021; Kyzdarbekova et al., 2014).

In modern social science literature, integration means combining two or more components into a coherent whole, resulting in new characteristics and higher quality compared to a simple arithmetic set of characteristics of the parts to be combined (Weber, 1974). The history of society, the history of journalism and literature are interrelated processes. The unity between them is direct, the leading role remains in objective social factors. Journalism has a significant impact on the development of public consciousness. It establishes and predicts the changing relations between a person and the world, which is truly inherent in literature (Yessenbayeva et al., 2020; Serdali et al., 2016).

Literary journalism is a direct product of the integration of journalism and fine literature. The methodology and theory of their similarity and proximity are sufficiently reflected in the specialised literature. Authors and publicists of works of artistic journalism are united by the ability to master and combine the artistic method of portraying the truth. In the productive and creative integration of journalism and fine literature, such stylistic varieties of journalism as fiction, business, autobiographical, poetic, dramatic are intensively developed. Journalism in literature is a unique and holistic phenomenon, an attribute of the modern literary process and an attribute that determines its meaning and content. On the one hand, it is considered as a qualitative ideological and expressive tool in a specific work, on the other hand, as a stylistic factor in the creative process, which is covered in a large collection of works of a certain historical era and determines creative aspirations and ways of depicting reality. Journalism in literature is, first of all, the relevance of the subject of literary creativity, which in its sustainable development is determined and closely related to such ideological and aesthetic qualities as relatability, authenticity, and truthfulness to reality. It is evident that many of the works that were relevant at that time were described by acute, socially significant conflicts, the 
authors' attention to urgent problems, the attitude of contemporary readers to direct, constructive conversation about the main problems of present and future (Atabekova, 2020; Markova et al., 2019; Dautova et al., 2017).

In a number of articles, M. Weingarten (2006), Ch. Flippen (1974), J. Hollowell (2016), N. Mills (1974), T. J. Masharipova (2014), A. D. Khasavova (2019) note the conceptual contrast of literary cyclicality and journalistic linearity at the level of metaphysical interpretation of reality given in the figures of Plato and Aristotle. Thus, the founder of idealism raises being to the level of an idea-image and thereby gives an ontological status to literary fiction. On the contrary, metaphysical substantialism, maximally filtering all the sublime poetry of Plato to the conceptual core, reduces the volume of literary imagery into the paradigm of rational inferences. The price of the metalanguage translation of the Platonic object-language turns out to be the unfolding of the cyclical nature of the literary image into the linearity of a journalistic fact. Research methods include structural and functional analysis, historical etymology.

\section{Materials and Methods}

According to T. Zh. Masharipova (2014), the specific meaning of the difference between literary fiction and journalistic factuality that emerged in the era of the ancient archaic in the case of continuity between Plato and Aristotle turns out to be the transformation of a fictional mythical image into a predicate of a logical and rhetorical subject. The essence of such a transformation is the gap between the cyclical completeness of the world in the mythological utterance and the historical-linear fragmentariness of journalistic discourse (Polonsky, 2018). According to A. V. Khasavov (2019), in Aristotelianism, the ontological rationale for translating the sacred names of myth into the forms of universal categories is the substantial establishment of a fixed point of linear reading of all the mobile and historically concrete reality. This position is quite applicable to the genesis of journalistic authorship, taking the bearing in its temporal-spatial coordinates (Johnson \& Wolfe, 1973).

In several centuries this poetic structure will be reproduced in the literature of the New Testament. According to V. I. Khomyakov, the apostles, responding in a journalistic manner to the event of the life, execution and resurrection of their mentor Jesus Christ, with high verbal artistry give the author's narration of these historical events (Khomyakov \& Andreeva, 2017). So much so that the Gospel of Matthew cannot be confused with the Gospel of John. As a result, gospel expositions further became the basis of Christian doctrine. Thus, before the monotheistic Middle Ages, the European literary and artistic tradition made the most radical turn from the syncretism of epic, drama, and lyric poetry in myth to the conceptual diversification of literary genres through the substantialisation of the author's position. Interpretation of the content of sacred names into categorical forms, Aristotelian inventions of logic and rhetoric, the opening of the space of the public word, which sounds in the mouth of a person as a "political animal", share the literary image and the journalistic concept (Yıldırım, 2020; Atabekova et al., 2018).

In the era subsequent to antiquity, the word retains its sacredness, being confirmed by biblical authority. But unlike the previous era, in the Middle Ages, the Word, being detached from a natural thing, acquires authorship. Inspiring the idea of an absolute personality in the verbal consciousness of medieval Europe, monotheism divides the once unified sphere of literature into two scenes - the genuine scene of the real creation of the world by God's name and the conventional scene of depicting the world with signs of artistic symbolisation (Khasavov, 2019). The symbolism of medieval poetics asserts the highest limit. Belonging by birthright to the preceding era of poetics, in the Middle Ages the symbol reaches its artistic maturity. V. Slavina notes that although the semantics of the rhetorical word is firmly limited from the outside, this "does not exclude the existence of another layer of 
meanings hidden from the creative and perceiving consciousness under this semantics, which are still generated by mythological thinking and are historically a derivative basis for rhetorical semantics" (Slavin, 2016). Notably, in the period of Kievan Rus and Muscovy, the connection between literature and journalism went through a similar genesis (Masharipova, 2014; Chen et al., 2020). According to V. Slavina (2016), the head of state, on the one hand, as an ordinary person, is divided between the necessity of guaranteeing the enforcement of the law, which "denies violence by violence", and no law is capable of obliging the autocrat to carry out God's will. But it is in the good will of the autocrat to admit by their faith the miraculous possibility of admitting God's will in oneself. Therefore, "the king is by nature similar to all people, while in power he is similar to the Almighty God".

The new European worldview has placed a person with their unique ability of intelligence at the centre of the world. M. Weingarten (2006) is convinced that "the theoretical initiative of the anthropocentric turn belongs to Rene Descartes". The prominent French philosopher, mathematician, physicist with a special intellectual algorithm cogito considers the human self as the centre of coordination of the picture of the world. Following the closure of the picture of the world to the self, all social forms and institutions are also focused on the human subject. Modern times are reformatting all the old literary and journalistic genres. The centre of gravity of this reformatting is filling the author's position with the content of autonomous subjectivity. According to A. D. Khasavov (2019), "the previous novel of the eras of antiquity and the Middle Ages did not know an autonomous, independent author-creator, since the absolute perspective of seeing reality was communicated to him by involvement either in Nature or in God, on whose behalf he spoke".

According to M. M. Bakhtin (1986), Rabelais opens the cyclical plot of the world in the "spacetime series of growth-becoming" (Flippen, 1974) of the Modern Age. C. Polsgrove believes that it is from the Rabelaisian carnival of the ancestral flesh that the hero of Cervantes' (1547-1616) novel "The cunning hidalgo Don Quixote of La Mancha" recoils with disgust, hoping to return to the ideals and values of the Middle Ages, which once constituted the unshakable neighbourhood of the habitat of the eternal spirit, the periphery of divine eternity (Polsgrove, 1995). Alas, this return turns out to be tragically impossible.

The reason for this impossibility is the natural duality of a person into contrasting spirit and body, Don Quixote, with his tallness and thinness symbolising nobility and sublimity of the spirit, is weighed down by his body in the form of a pot-bellied, down-to-earth, selfish Sancho Panza, a kind of Rabelaisian character, clearly symbolising the ancestral flesh in its opposition to spirit. According to M. Weingarten, "having overcome the Rabelaisian substitution of the eternal spirit with mortal flesh, embodied in the paternal-filial unity, Cervantes transfers this external difference to the internal gap between the "journalistic" vertical of the author's I and the "literary" horizontal of the hero's spirit (Weingarten, 2006). And the next piece makes a kind of twist from this unbearable split. In the play "Hamlet" by W. Shakespeare, the real spirit of the heavenly Father ultimately transforms into a hallucinatory illusion, in fact, into the "ghost of the father". It is only the spirit of the autonomous subject, on a single axis of which the "journalistic" author and the "literary" hero find themselves (Kravtsov et al., 2019; Temirbolat et al., 2016; Soloviova, 2020; Kondratenko et al., 2021).

The vertical of this lever with the ethical "father"-author at the top and the aesthetic "son"-hero at the bottom, reaches total rest at the point of absolute authorship (Weingarten, 2006). The same vertical completely determines the structure of the entire Shakespearean theatre, in which the "father's" director-author reigns supreme over the "filial" actor-character. In the phenomenon of the vertical of the "fatherly" author's domination over the "filial" characters, the author of the classic novel of the Modern Age becomes crystallised, enclosed in the unity "I am the author"/ "I am the hero" (Masharipova, 2014). 
Thus, as a result of the history of integration of the genres of literature and journalism that have developed over two and a half millennia, there was a preponderance of the linear vertical of the "journalistic" author as a subject over the cyclical horizontal of the "literary" world as an object based on the position of the author fixed on the I. There are many types of myths in the world, and the most common ones are shown in Table 1.

Table 1. Common types of myths

\begin{tabular}{cl}
\hline Types of myths & \multicolumn{1}{c}{ Characteristic } \\
\hline Cosmogonic & $\begin{array}{l}\text { Myths that describe the emergence of the world through the } \\
\text { actions of the Gods. } \\
\text { Theogonic }\end{array}$ \\
$\begin{array}{l}\text { Myths about the origin of the Gods, from whom they were } \\
\text { created, about their struggle for power and the formation of } \\
\text { the pantheon. } \\
\text { Anthropological }\end{array}$ & $\begin{array}{l}\text { Telling about the creation of human, his essence and the fate } \\
\text { intended for him by the Gods, about the meaning of his } \\
\text { activities on Earth and the meaning of his life. }\end{array}$ \\
Cosmological & $\begin{array}{l}\text { Describing the construction and development of the world. } \\
\text { Etiological (calendar) }\end{array}$ \\
About the change of time cycles - day and night, winter and \\
summer, up to cosmic cycles. \\
Myths about animals.
\end{tabular}

\section{Results and Discussion}

According to Yu. Revvo (2018), as early as in the era of romanticism, which arose at the turn of the 18th-19th centuries, with the emergence of a new type of hero, completely disillusioned with the gifts of urban culture and industrial civilisation, and escaping from them into the wilderness, into the countryside, into nature, the realisation comes that it is not a lack of education and upbringing. On the contrary, the bearers of the romantic consciousness see evil not in the lack of culture, but in its excess. And the reason for this excess is the maximum distance of a person from his eternal beginnings heaven and earth. V. Khomyakov is sure that within the aesthetics of romanticism begins a departure from the linear novel with an absolute, "all-knowing" author in the centre, developing the methodology, according to M. Bakhtin (1986), of the "polyphonic" novel, marked by the poetics of F.M. Dostoevsky events (Khomyakov \& Andreeva, 2017). The "polyphonicity" mainstreamed by Bakhtin, in fact, means the implementation of a reversal from the causal linearity of the "journalistic" logos to the cyclical nature of the "literary" myth (Kamruzzaman et al., 2019; Temirbolat et al., 2015; Prystai, 2021; Kohut, 2021).

Admittedly, the mythical cyclicality is not a reason for sublime arrogance to the low factuality of current transience. We know Dostoevsky as a brilliant publicist who responded to all the significant events of his time, be it the conflict in Montenegro between the Slavs and Turks in 1862, or the publication of the Russian translation of Victor Hugo's novel Notre Dame Cathedral in 1863. The journalism of F. Tyutchev, who in his articles and letters sharply reacted to the anti-Russian (or as it would be called now, Russophobic) sentiments of the French and German public, at the same time pointing out the indissoluble ties between the cultures of the three countries, especially welcoming the rapprochement of Russia and Germany based on his own passion for German romanticism (Slavina, 2016). Thus, the journalism of Dostoevsky and Tyutchev is of a special kind. It is not literature that is the "servant" of journalism here. On the contrary, journalistic comments complement the literary 
position of their authors. In the 20th century, the integration of literature and journalism reached a new level. And the article "based on true events" that emerged from its depths, indexes a significant number of literary and cinematic works, confirming the maxim that life is richer than the most sophisticated fiction. According to the solidary opinion of American researchers J. Hollowell (2016), N. Mills (1974), and C. Polsgrove (1995), the phenomenon of new journalism was the result of the convergence of literary fiction and journalistic non-fiction.

Works in the genre of new journalism are described by the rejection of frank fiction and pretentiousness, autobiography, photographic accuracy of displaying reality, an abundance of details of everyday life and everyday colloquial speech. This prose is distinguished by the shortening of the reflexive distance of the so-called "literary device", which makes the reader feel that the author, hiding behind fictitious characters and plots, is "fooling" him (Mills, 1974). On the other hand, pure reliance on journalistic documentary does not allow the work to be completed, since, unlike the story being told, the real story does not end. And this makes the presence of a plot inevitable as a "compromise education" that combines the lightness of literary fiction and the severity of journalistic fact. That is, in such literature, reality is collected in a double movement of expanding the "reflexive" narrowness of the author's subject and narrowing the "communicative" breadth of the world object (Masharipova, 2014). In this interpretation, the situation allegedly is that after losing the Cold War, the outcome of which was predetermined by "the USSR being a kind of a sorry excuse of America, struggling to worm itself into the real deal America", the conservative part of the former political and cultural elite of the USSR fell into an experience of "post-imperial syndrome" (Pelevin, 2019). And what previously could be subtracted only in the heavy discourses of eminent political publicists such as F. Fukuyama and Z. Brzezinski, now easily fits into easily read literature. And at the same time, Pelevin's fiction absolutely resonates with the discourse of the publicist G. Guseinov (2017): “...the Soviet people, as has been repeatedly proved by the entire subsequent history of the USSR, did not win any victory. Stalin won, and the people survived, the fewer witnesses of that war remain, the more arrogance have those who turn this day into a propaganda gala concert with a St. George ribbon instead of a serpentine streamer...”.

\section{Conclusions}

In conclusion, the dialogue of these two - literary and journalistic - discourses, enriching each other, ultimately gives them the opportunity to go hand in hand towards complete merging and mutual absorption. This is on the one hand. On the other hand, mythical imagery ignores the factuality of reality, which is always perceived in the perspective of temporal linearity, and thus gives the experience of the fullness of the world. At the same time, journalistic discursiveness, due to the strict historical specificity of the author's position, regarding which only tendentious integration of facts is possible by the type of concatenation of causes and their consequences, places itself in the boundaries of epoch-making topicality.

The creative integration of these genres allows the current topicality of journalism to take part in eternal literary topicality. Thus, in the ancient and medieval history of literature, there was a close integration of the literary image with the culmination of the novel, in which epic, dramatic, lyrical, and journalistic interpretations of a particular historically real and contemporary author were synthesised. The rapidly changing socio-economic landscape of Europe has radically defined its cultural life in the form of a multitude of new art forms, genres, styles, and trends. A wide field of secular literature and journalism appeared. And if in the Middle Ages the content of a person's spiritual life was determined primarily by his participation in the ceremonies of the official church, nowadays a person translates the inner plane of their spiritual being into the inner plane of their existence, giving the secret nature of faith in God. 
In modern secular world, spirituality is reflected in reading, going to the theatre, and conversation. The secular formats of literature and journalism have become a field of cultural communication reflecting the spiritual life of European society. Because of their existential features, literary and journalistic works are a clearer mirror of the "big" history than the historical and geographical observation of changes in mass phenomena in politics and economics. This allowed the French semiotics and literary critic Roland Barthes to suggest that one day "the history of literature will turn out to be history as such".

For modern science, the connection between journalism, literature, and art is far from exhausted. The integration of journalism and fiction, as well as their analysis at different stages of development, are not of practical, but of scientific interest. A comprehensive study of integrative creative ties in the field of "Journalism - Literature - Art - Science" will allow to better understand the phenomenon of the past. The systematic and comprehensive nature of such research helps optimise the journalistic process, which must be formed and demonstrated by itself, but is based on a solid foundation of science. Productive and creative integration of journalism and fiction can only develop if the features, innovative aspirations of publicists and writers are systematically studied and considered. To this end, it is necessary to coordinate the publication of the best literary and journalistic works, creative stories and collections of journalistic writers, analytical reviews of trends in the development of literary and journalistic work, methodological literature.

\section{References}

Atabekova, A. (2020). Language representation of youth health concept in international institutional discourse. Systematic Reviews in Pharmacy, 11(12), 1417-1427.

Atabekova, A.A., Gorbatenko, R.G., Shoustikova, T.V., \& Valero-Garcés, C. (2018). Cross-cultural mediation with refugees in emergency settings: ICT use by language service providers. Journal of Social Studies Education Research, 9(3), 351-369.

Bakhtin, M. M. (1986). Aesthetics of verbal creativity. Moscow: Iskusstvo.

Chen, G., Jiang, Z., \& Kamruzzaman, M.M. (2020). Radar remote sensing image retrieval algorithm based on improved Sobel operator. Journal of Visual Communication and Image Representation, 71,102720 .

Dautova, G., Azibayeva, B., Aimukhambet, Z., Sarekenova, K., \& Abilkhamitkyzy, R. (2017). The image of defender-hero in historical eposes. (On the materials of the Kazakh epics). Ponte, 73(10), 215-223.

Elnikova, O. E. (2019). Journalism of the literature of kievan rus: texts, authors, audience. Yelets: I. A. Bunin Yelets State University.

Flippen, Ch. C. (1974). Liberating the media: the new journalism. New York: Acropolis Books.

Guseinov, G. Ch. (2017). The noughties at the tip of the tongue: a brief guide to russian discourse. Moscow: Delo.

Hollowell, J. (2016). Fact \& fiction: The new journalism and the nonfiction novel. Boston: Harvard Publishers.

Hoque, M. A., Ali, M. M., Puteh-Behak, F., \& Baharun, H. (2021). Lexical borrowings from the English language into bangla short stories. Journal of Language and Linguistic Studies, 17(1), 158172. 
Issakova, S.S., Kultanbayeva, N.K., Kushtayeva, M.T., Saduakas N.A., Aitbenbetova, A.K., \& Imangazina, A.A. (2021). Fairytale discourse as a demonstration of the national mentality (On the material of Kazakh and Russian fairy tales). Astra Salvensis, 2021, 121-135.

Johnson, E. W., \& Wolfe, T. (1973). The new jornalism. New York: Harper \& Row.

Kamruzzaman, M.M., He, W., \& Peng, X. (2019). Performance of relay assisted uplink wireless communication using multi-layered STBC for multiple access channel. Telecommunication Systems, 71(3), 309-320.

Khasavov, A. D. (2019). Socio-anthropological features of journalistic discourse in the context of media communications. Communicology, 7(2), 67-82.

Khomyakov, V. I., \& Andreeva E. A. (2017). Artistic and journalistic genres of print media: history and modernity. Moscow: Direct-Media.

Kohut, O.O. (2021). Interpretation of the category of stress resistance in psychology. Scientific Bulletin of Mukachevo State University. Series "Pedagogy and Psychology”, 7(1), 79-89.

Kondratenko, N.Yu., Marchenko, H.V., \& Stezhko, S.O. (2021). Psychological and pedagogical principles of development of communicative competence of future journalists based on linguoculturology. Scientific Bulletin of Mukachevo State University. Series "Pedagogy and Psychology", 7(1), 113-120.

Kravtsov, Y.S., Chetnverikova, N.A., Saifnazarov, I.S., Dombrovska, O.V., \& Khovpun, O.S. (2019). Philosophical purpose of social communication in the aspects of sustainable development of modern social reality. Asia Life Sciences, 1, 329-337.

Kyzdarbekova, M.A., Serdali, B., Bakirova, Z.A., Nurtazayeva, N.M., Doszhan, S.M., Kasymbekova, K.A., Djamalova, S.A., \& Bimaganbetova, A.K. (2014). Nonverbal means of pedagogical dialogue in conditions of cross-culture communication. Life Science Journal, 11(Spec. Issue 6), 238-244.

Markova, E., Lyzlov, A., \& Balkhimbekova, P. (2019). Evaluative aspect in the semantics of phraseological units with the toponymal component. Opcion, 35(88), 237-252.

Masharipova, T. Zh. (2014). Journalism and literature: general and distinctive features. Moscow University Bulletin. Series 10. Journalism, 2, 130-148

Mazhitayeva, S., Tazhikeyeva, A., Khan, N., Ayazbaeva, B., Tuite, E., Nygmetova, N., Sembiyev, K., \& Kenzhegaliyev, S. (2014). Lexicon and national realias: Borrowed words, loan words, exoticisms, anglicism. Life Science Journal, 11(Spec. Issue 6), 122-128.

Mills, N. (1974). The new jornalism: A historical antology. New York: McGraw Hill.

Pavenkov, O., Rubtsova, M., \& Shmelev, I. (2018). The transformation of gender visualization in photography: Soviet and Russian multisemiotics. Discursos Fotograficos, 14(24), 219-256.

Pelevin, V. O. (2019). The art of light touch. Moscow: Elena Shubina Publishing House.

Polonsky, A. V. (2018). Journalism as a special kind of creativity. Scientific bulletin of BelSU, 11(51), 56-61.

Polsgrove, C. (1995). It wasn't pretty, folks, but didn't we have fun?: Surviving the 60s with esquires harold hayes. New York: W. W. Norton \& Company. 
Prystai, H.V. (2021). Methodological foundations of the development of professionally-oriented sociocultural competence of a foreign language teacher using the newspaper material. Scientific Bulletin of Mukachevo State University. Series "Pedagogy and Psychology", 7(2), 18-24.

Revvo, Yu. A. (2018). Fine literature and journalism of the first wave of Russian emigration in the English-speaking cultural context. MITU-MASI Bulletin, 1, 53-59.

Serdali, B.K., Ashirbekova, G.S., Orazbekuly, K., \& Abiev, B.M. (2016). Genres of modern mass media. Mathematics Education, 11(5), 1075-1085.

Slavina, V. A. (2016). In search of the ideal: literature, criticism, journalism of the first half of the 20th century. Moscow: Flinta.

Smagulov, Z.K., Kalybekova, K.S., Takirov, S.U., Babashov, A.M., Aubakirov, N.M., Kenzhegaliyev, S.A., Nurzhanova, K.K., \& Zhumageldin, Z.S. (2014). Sh. Ualikhanov and theories of mythological school in Russian literal study. Life Science Journal, 11(9 Spec. Issue), 202-206.

Soloviova, O. (2020). Personal features of identification and uniqueness in the anthropological field of social discourse. Visual Anthropology, 33(1), 81-100.

Temirbolat, A.B., Abdikulova, R.M., Kalkabaeva, S.A., Ospanova, A.A., \& Ospanova, A.A. (2015). Transformation of Novel's genre in modern literature. Mediterranean Journal of Social Sciences, 6(4S2), 333-339.

Temirbolat, A.B., Daribaev, S.D., Imakhanbet, R.S., Ospanova, A.A., \& Ospanova, A.A. (2016). Influence of mass literature on the reader's consciousness. Global Media Journal, 2016, 1-6.

Weber, R. (1974). The reporter as artist: a look at the new journalism controversy. Los Angeles: Hastings House.

Weingarten, M. (2006). The gang that wouldn't write straight: Wolfe, Thompson, Didion, and the new jornalism revolution. New York: Crown Publishers.

Yessenbayeva, A.M., Yelikbayev, B.K., Abdrahman, G.K., Makulova, L.T., \& Serdali, B.K. (2020). Investigating the communicative functions of interrogative sentences in dialogue texts. Media Watch, 11(3), 488-501.

Yıldırım, F. Ç. (2020). Language choice and identity: An investigation based on the comparison of language attitudes from two different localities. Journal of Language and Linguistic Studies, 16(2), 1032-1042.

\section{AUTHOR BIODATA}

Raissa Saddykova is Doctoral Student, Department of Philology, Kazakh Humanitarian Law Innovative University, Semey, Republic of Kazakhstan.

Raushan Mukhazanova is Ph.D. in Philology, Senior Lecturer at the Department of Philology, Kazakh Humanitarian Law Innovative University, Semey, Republic of Kazakhstan.

Assem Kassymova is Ph.D., Head of the Postgraduate Education Center, Kazakh Humanitarian Law Innovative University, Semey, Republic of Kazakhstan.

Gulnur Kabdullina is Master in Philology, Researcher at the Scientific Department of Humanities, Shakarim State University of Semey, Semey, Republic of Kazakhstan.

Assem Yelubay is Senior Lecturer at the Department of Aviation English, Civil Aviation Academy, Almaty, Republic of Kazakhstan. 